\title{
'VICTIMS’ VERSUS ‘OFFENDERS’ IN BRITISH POLITICAL DISCOURSE: THE CONSTRUCTION OF A FALSE DICHOTOMY
}

\section{DEBORAH H. DRAKE and ANDREW J. HENLEY}

Deborah Drake is Lecturer in Criminology, Department of Social Policy and Criminology, Open University; Andrew Henley is a PhD student and Graduate Teaching Assistant, School of Sociology and Criminology, Keele University

Abstract: This article evaluates the contemporary discursive status of victims and people convicted of criminal offences. The rhetoric used by British politicians to convey the meaning of 'rights' is explored within media output, parliamentary speech-making and other forms of political discourse. Our analysis details how victims' rights are sometimes advocated for at the expense of 'offenders'" rights in public discourse. Examination of parliamentary debates illustrates that differentiating between 'victims' and 'offenders' elides consideration of more meaningful support for victims, worsens opportunities for the reintegration of ex-prisoners and constructs a false dichotomy between citizens who do not fall into mutually-exclusive categories.

Key words: human rights; prisoners; populist punitiveness; disenfranchisement

The Prime Minister: It makes me physically ill even to contemplate having to give the vote to anyone who is in prison. Frankly, when people commit a crime and go to prison, they should lose their rights, including the right to vote. (Hansard, HC Debates, vol. 516, col. 921, 3 November 2010)

The above quotation from David Cameron exemplifies the willingness of some politicians to engage in populist posturing through the rhetorical denial of basic rights of citizenship for an unpopular minority - in this case, voting rights to prisoners. This extraordinary statement might be viewed as an example of Bottoms's (1995) notion of 'populist punitiveness' which conveys 'the notion of politicians tapping into, and using for their purposes, what they believe to be the public's generally punitive stance' (p.40). In the wake of rising prisoner numbers 
and an apparent shift towards increased political concern with 'public opinion' and victims of crime (Drake 2012), there has been sustained criminological focus on punitive discourses and the implementation of harsher criminal justice policies (Garland 2001; Pratt et al. 2005; Zimring and Johnson 2006). This enactment of what Snacken (2010) calls a 'populist' form of democracy utilises a political approach that places much emphasis on the perceived will of the majority at the expense of the interests of unpopular, and less powerful, minority groups or those who have been labelled as 'other'.

Within this context, debates associated with human and civil rights often seem to descend into a zero-sum game where victims’ rights are seemingly only won at the expense of the rights of accused persons or prisoners (Williams 2005; Hall 2009). This binary positioning of perpetrators or prisoners versus victims is a powerful ideological move. It casts victims, and those accused or convicted of criminal conduct, as distinct, polarised opposites (Zedner 2004; Dignan 2005; Bednarova 2011). Further, by politicising the issue of victims' versus 'offenders'” rights a clear delineation is drawn between those who are 'deserving' of legal protections and those who are not. Such delineations encourage narratives which construct the 'criminal' or the 'prisoner' as having actively forfeited their rights and are in keeping with discourses that define lawbreakers as 'other' (Drake 2012). Whilst such crude binary constructions have often appeared in media discourses in the wake of particularly violent or high-profile crimes, there has been an apparent increasing reliance on a zero-sum approach to victims' and offenders' rights in political rhetoric in Britain since the early 1990s (Sanders 2002).

The way discourse is used to construct ideas about social deviance, crime and 'offenders' has been an area of sustained criminological attention (Walker and Boyeskie 2001). Cohen's (2002) work on constructions of young people as 'folk devils' and the emergence of 'moral panics' has framed much critical analysis aimed at examining 
constructions of deviance and dangerousness. Recent research in this area focuses more intently on the role of tabloid newspapers (and even fictional accounts of imprisonment) in the shaping of public attitudes towards the 'criminal' and the supposed 'soft' conditions of imprisonment in the UK (Mason 2007; Cheliotis 2010). Media coverage on political thinking concerning crime and justice conveys increased political concern with 'public acceptability' regarding prison conditions and regimes. For instance, in 2009 it was reported that HM Prison Service had:

... warned governors to ensure all activities are 'acceptable, purposeful and meet the public acceptability test' ... governors have been told they must consider how activities 'might be perceived by the public and victims' and avoid 'indefensible criticism' that undermine public confidence in the Prison Service. (Independent on Sunday, 25 January 2009)

This media account followed a direct order from the then Justice Secretary, Jack Straw, who, it was claimed, was embarrassed by tabloid reports of a stand-up comedy class being run in a high-security prison. More recently, David Cameron, in a speech announcing details of his government's 'rehabilitation revolution' has asserted the need for a criminal justice policy which is 'tough but intelligent' (tellingly he used the words 'tough', ‘toughen' or 'tougher' 24 times in the speech and 'rehabilitate' only seven) (UK Government 2012). Meanwhile, Cameron's Justice Secretary, Chris Grayling, has announced a range of reforms to prison conditions which will include banning 18 certificate DVDs, making new prisoners wear a uniform for the first two weeks of their sentence and making access to prison gymnasia contingent on engagement with work and rehabilitation programmes ( $\underline{B B C \text { News }}, 30$ April 2013).

This article contributes to these debates by undertaking a selective, but critical, analysis of British political discourse on issues associated with the rights of lawbreakers and victims of crime. It focuses on the ways in which lawbreakers come to be seen as 'other', arguing that violent and high-profile crimes and criminals are often the basis on which such 
constructions are formed (Drake 2011, 2012). It is shown that political and media discourses also frequently refer to 'offenders': a homogenous label which implicitly constructs as 'other' anyone who is known to have contravened the law and served a prison or other courtprescribed sentence. We argue that the label 'offender' and the associated processes of 'othering' set up a false dichotomy between citizens, based upon the idea that experiences of victimisation and offending are mutually-exclusive phenomena. Furthermore, by examining the rhetoric of parliamentary speech-making, media output and other forms of public discourse, we demonstrate the ways in which victims' rights and 'offenders'” rights are dichotomised. This, we suggest, effectively creates two distinct categories - 'law-abiding citizens' who are deserving of rights and State protections and 'law-breaking denizens' who, by virtue of their 'outsider' status and criminal records, are marginalised and cast into the emerging global precariat (see Standing 2011). We conclude that these tactics have longerterm implications for the social reintegration of those who have contravened the law and prevent the emergence of more meaningful and productive strategies for supporting victims.

\section{'Victims', ‘Offenders’ and Divisive Discourse}

The construction of all lawbreakers as 'offenders' can be seen as problematic when considered alongside the following information regarding the launch of the Police National Database in 2011 by the National Policing Improvement Agency:

The Police National Database (PND) will be used by a total of 53 police bodies in England, Wales, Scotland and the British Transport Police. Up to 15 million people's details are estimated to appear on the database ... Around 9.2 million people on the database will have criminal records, with others there for more minor offences or because they have been brought to police attention. (Computer Weekly, 22 June 2011)

Within this context, rhetorical appeals to the collective sentiments of a 'law-abiding majority' become difficult to justify, since the data refer only to those 9.2 million actually convicted of 
criminal offences. The 'dark figure of crime' and the problem of unreported criminal activity has been an issue that has long bedevilled those who attempt to quantify crime patterns (Coleman and Moynihan 1996). Thus, it might be argued that many millions more have committed criminal offences which have remained undetected and unprosecuted. Furthermore, the idea that perpetrators and victims of crime are always mutually-exclusive categories is a false assumption since there is often overlap between the demographic profiles of those who are statistically more likely to be at risk of crime victimisation (Chaplin, Flatley and Smith 2011) and those who may be at risk of involvement in criminal activity (Webster, MacDonald and Simpson 2006). Karstedt and Farrall (2006) have also discussed 'the crimes of everyday life', those offences which:

are committed by those who think of themselves as respectable citizens, and who would definitely reject the labels of 'criminals' and 'crime' for themselves and their actions. Politicians refer to them as the 'law-abiding majority in this country', ignoring the fact that the majority does not abide by the law, or at least is highly selective in when to comply and when not to. (p.1011, italics in original)

Dividing 'victims' and 'offenders' into distinct groups in the public imaginary might be considered as an outcome of cultural representations of crime and justice. The murder of two-year-old James Bulger in 1993 by two ten-year-old boys is often cited as a watershed case in media coverage (see Green 2008), which provided a significant opportunity for the ruling Conservative government to assert a populist position as the party for law and order. Only a few days after James Bulger’s body was discovered, Prime Minister John Major asserted his tough stance on crime in a newspaper interview and drove a clear wedge between victims and 'offenders' by saying: 'I would like the public to have a crusade against crime and change from being forgiving of crime to being considerate to the victim. Society needs to condemn a little more and understand a little less' (Mail On Sunday, 21 February 1993). Haydon and Scraton (2000) examine the shift in political and public discourse on crime following the Bulger murder as part of a wider consideration of the rights' implications of this 
case for the youth justice system. They conclude that the case had at least three significant consequences for the future of criminal justice policy in the UK:

First, it initiated a reconsideration of the social construction of ten-year-olds as 'demons' rather than 'innocents'. Second, it coalesced with, and helped to mobilize, a moral panic about youth crime in general. Third, it legitimated a series of tough law-and-order responses which came to characterize much of the 1990s. (p.447)

The period following the Bulger case is often linked with the emergence of an almost hegemonic centre-right political consensus on issues of criminal justice (Downes 1998; Downes and Morgan 2002). Whilst Tory Home Secretary Michael Howard was advocating the use of incarceration on the basis that 'prison works', the Labour Party, desperate to shed its perceived image as being 'soft on crime', was reborn under Tony Blair as New Labour - a party which promised not only to be 'tough on crime' but also 'tough on the causes of crime' (Sim 2009). Consequently, the political landscape in Britain shifted toward a more populist form of democracy that has laid the foundations on which clearer and deeper divisions have been drawn between victims and lawbreakers. Under the New Labour government, which was eminently concerned with projecting its new 'tough on crime' image in both the media and the court of public opinion, discourses emerged which drew dividing lines between the victims of crime (deserving of sympathy and compassion) and 'offenders' (in need of 'tough' responses). As Garland (2001) has commented:

The penal-welfare approach proceeded as if the interests of society and the interests of the offender could be made to coincide. Rehabilitating offenders, reforming prisons, dealing with the root causes of crime - these were in the interests of everyone. Money spent on treating the offender and improving social conditions would be repaid by falling rates of crime and a better-integrated citizenry. The treatment of offenders was a positive sum game. Today the interests of convicted offenders, insofar as they are considered at all, are viewed as fundamentally opposed to those of the public ... In consequence, and without much discussion, the interests of the offender and even his or her legal rights, are routinely disregarded. (p.180) 
In July 2006, the government published a discussion document entitled Rebalancing the Criminal Justice System in Favour of the Law-abiding Majority. This report included a foreword by Tony Blair which expressed concern that: 'The public believe that the system shows more concern for protecting the rights of those who break or ignore the law than those who keep it' (Home Office 2006, p.2). However, the report provided little evidence of the validity of this premise or how it had been established. As Loader (2006) argued, there was no clear argument presented as to what constituted the imbalance or on what grounds it was being claimed that the public perceived there to be an imbalance. In his response to the discussion document he stated:

I simply think you need to offer more serious evidence than any I have seen that this [imbalance] is in fact the case, rather than simply assert that it is so, or that 'the public' believes it to be so ... The idea of balance almost always functions in these discussions as a piece of rhetorical trickery ... It offers no criteria whatsoever for determining what the right 'balance' looks like, sets up the whole debate as an entirely zero-sum game between 'criminals' and 'victims', and offers no resources for protecting the criminal justice system from utilitarian calculation. (Loader 2006)

More recently, the role of 'Victims' Commissioner' has been established 'to listen to the views of victims and witnesses, understand the criminal justice system from their point of view and try to help improve the services and support available' (Ministry of Justice 2012). This long-overdue arrangement provides some response to continued criticism that the criminal justice system has historically failed victims (Dignan 2005). Indeed, greater victim involvement in the administration of criminal justice has been seen by many victims' rights' groups as a positive (if still tokenistic) development (Walklate 2007). Yet, whilst there may be some satisfaction on the part of victims' rights' campaigners and segments of the general population when attempts to alter foregoing criminal justice processes are successful, such measures do not tend to result in a more meaningful recognition of the loss experienced by victims of serious crime. The role of victims within criminal justice policy formation is often more symbolic and rhetorical than meaningful (Bottoms 1983; Karmen 1992; Walklate 
2007). Sim (2009, p.158) argues that surveys reveal that victims can be sceptical of the capacity of the prison and punitive measures to solve problems of crime. Yet these voices have generally been ignored, with political rhetoric and crime policy in Britain gravitating toward those voices calling for a more retributive response.

In marked contrast to the growing sensitivity accorded to crime victims, lawbreakers are increasingly the targets of vilification in political discourse. The government response to the Breaking the Cycle Green Paper (Ministry of Justice 2010, 2011) - purportedly the blueprint for a 'rehabilitation revolution' - pledged commitments to the rights and needs of victims within the context of an expressly punitive language about the purposes of the criminal justice system. A quotation attributed to Chris Grayling's predecessor, Kenneth Clarke, at the beginning of the response states: 'A firm, fair justice system which keeps the law-abiding safe and gives law-breakers their just deserts is the most fundamental thing a state should offer its citizens’ (Ministry of Justice 2011, p.1). This rhetoric presents an image of a 'powerful state' that is cast as the protector of the rights of 'good citizens', guaranteeing serious consequences for those who contravene the law. Against this backdrop, the withholding or curtailment of 'offenders'” rights may be seen as holding symbolic purchase in reinforcing political legitimacy through promises of public safety. Drawing discursive connections between safety, 'good' citizenry, and the powerful State suggests a rationale for disregarding the citizenship and rights of lawbreakers who are, presumably, not offered those most 'fundamental protections' extended to the 'law-abiding public'.

These discourses and ways of thinking about the problems of crime produce and reproduce constructions of both victims and 'offenders' that are simplistic and onedimensional. Such constructions are instrumental in reinforcing existing fears and dominant beliefs about the problem of crime and about how those who break certain laws 'ought' to be treated. Furthermore, they draw clear delineations between the 'law-abiding' and the 
'dangerous' and between the 'deserving' and 'undeserving'. Within this policy context, 'offenders' are often crudely cast as undeserving of citizenship rights and State protections. Easton (2009, 2011) has persuasively argued the importance of the prisoner's right to vote and how the act of voting is a means of reaffirming the social contract. She argues:

For the offender, voting is, in some respects, even more important than for the ordinary citizen, because it is a reminder of one's duties under the social contract. It also reinforces a core value of democracy, namely equality. But denial of voting rights undermines civic respect and respect for the rule of law and thereby erodes the process of prisoner rehabilitation, which should include an understanding of the obligations and burdens of citizenship. (Easton 2009, p.232)

Instead, the current policy of denying prisoners the right to vote casts them apart from other citizens. Standing (2011) deploys the term 'denizens' to describe those members of society who do not possess the full range of entitlements that citizens do (that is, civil, social, political, economic and cultural rights):

The idea of the denizen, which can be traced back to Roman times, has usually been applied to foreigners given residency rights and rights to ply their trade, but not full citizenship rights ... In the wider world, most denizens are migrants ... However, one other category stands out - the large layer of people who have been criminalised, the convicted. The globalisation era has seen a growth in the number of actions deemed to be criminal. More people are arrested and more are incarcerated than ever before, resulting in more people being criminalised than ever before. (Standing 2011, p.14)

Issues of rights and citizenship (or $\underline{\text { denizenship) }}$ ) are, therefore, inextricably linked with issues of criminal justice. It is to the debates surrounding political rights for prisoners that we now turn.

\section{Votes for Prisoners: A 'Slap in the Face’ for Victims?}

The issue of citizenship rights and, in particular, the extension of the vote to prisoners in Britain has received much parliamentary and media attention. The UK's disenfranchisement of convicted prisoners dates back to the Forfeiture Act of 1870 which enshrined in law the concept of 'civic death'. This was further clarified by Section 3 of the Representation of the 
People Act 1983. Following a successful action taken to the European Court of Human Rights in 2005, the judgment in Hirst v. the United Kingdom [No. 2 ] (74025/01 [2005] ECHR 681) ruled that if the franchise was to be removed from convicted prisoners, then the measure needed to be compatible with Article 3 of the First Protocol of the European Convention on Human Rights (ECHR) which commits the UK to free and fair elections. The Hirst ruling, therefore, called on the UK to justify its departure from the principle of universal suffrage and effectively made the blanket ban on convicted prisoners voting unlawful (van Zyl Smit and Snacken 2009). Following prompts from the Committee of Ministers in the Council of Europe, the UK government announced proposals in December 2010 (UK

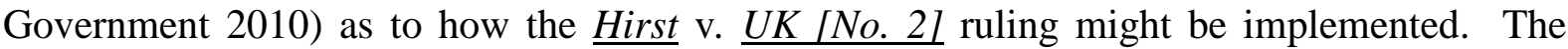
proposals, for the first time, indicated a differentiation between certain groups of prisoners, suggesting that those serving determinate sentences of less than four years might be given the franchise.

Media coverage of these debates, however, drew on aspects of the debate which reinforced constructions of all prisoners as equally undeserving of rights. For example, shadow Justice Secretary, Sadiq Khan, was reported to have quickly positioned victims of crime as central to his opposition to the proposals, describing prisoners' voting rights, as a 'slap in the face for victims of crime' (Sky News, 5 January 2011). Continuing this theme, he was also reported as stating that: 'The Government should be standing up for the victims of crime but instead they are slashing police numbers and giving dangerous convicted prisoners the vote' (Daily Telegraph, 20 January 2011). His stance on this issue was, perhaps, somewhat incongruous with his former role, not only as a leading human rights' solicitor, but also as a former chair of civil liberties pressure group, Liberty. Furthermore, his position ignored the fact that the issue was only now up for discussion due to the inaction of the previous Labour government in which he had served. Thus, there has been a general scarcity 
in both media coverage and political debate, of voices on either the left or the right supporting votes for prisoners. A cross-bench alliance was later formed between Labour’s Jack Straw (the former Justice Secretary who had failed to implement the $\underline{\text { Hirst }}$ v. $\underline{\text { UK ruling) and }}$ Conservative MP, David Davis, who together secured a parliamentary debate on the issue. Revealingly, Davis was reported to have claimed at the time that: 'I yield to no-one in my defence of human rights, but giving rapists the vote is not human rights' ( $\underline{B B C \text { News}}, 18$ January 2011).

The parliamentary debate took place on 10 February 2010 and the subsequent vote in favour of maintaining the voting ban for convicted prisoners was won overwhelmingly by 234 votes to 22 (although this turnout represented less than half of the total number of MPs). A number of speakers, on both sides of the House, explicitly discussed victims of crime within their speeches, initially dismissing the idea of prisoner voting on the basis that it may cause offence to victims:

although we do not get a lot of letters from prisoners demanding the vote, we will get a heck of a lot of letters from victims and their families if we give those people the vote? (Ian Paisley, Democratic Unionist Party: Hansard, HC Debates, vol. 523, col. 519, 10 February 2011)

Later contributions saw the re-emergence of the familiar theme which prompted the 'rebalancing the system' debates of 2006 and the idea of a criminal justice system which 'favoured' offenders over victims:

So often we hear our constituents complain that the legal system is on the side of the offender rather than the victim. (Tom Harris, Labour: Hansard, HC Debates, vol. 523, col. 548, 10 February 2011)

some people are keener to promote the rights of perpetrators of crime than those of victims of

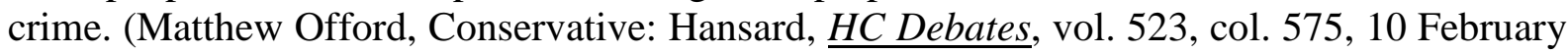
2011)

I find it extraordinary that we are talking about the rights of convicted criminals - people in prison - rather than the rights of those who are the victims ... the rights of criminals, as 
opposed to the rights of victims, are constantly discussed and put first. (Priti Patel,

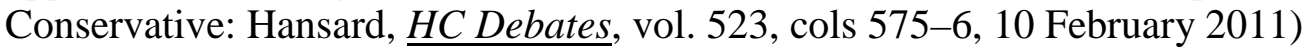

Amidst the debate there were very few voices in favour of recognising the rights of prisoners to vote. One speaker raised opposition to prisoner disenfranchisement and presented the viewpoint that there is no clear benefit to victims by denying citizenship rights to prisoners and expressed the opinion of Victim Support on this issue which has publicly endorsed the view that prisoners should have the right to vote:

Prisoners have committed a crime. Their punishment is to lose their liberty. That is fair and just. What is then gained by seeking to inflict civil death on them? In what way does that benefit the victim? ... The way we treat victims says a lot about the society that we strive to be, but the way we treat prisoners also says a lot about the society that we strive to be ... Interestingly, Victim Support, whose representatives I met a couple of weeks ago, is also of the view that prisoners should have the right to vote. I hope that Members will take that on board. (Tom Brake, Liberal Democrat: Hansard, HC Debates, vol. 523, cols 543-5, 10 February 2011)

However, such reasoning was largely marginalised by the dominance of 'victims before offenders' themes. The issues at stake when disenfranchising prisoners were neither debated nor thoroughly considered ${ }^{1}$ and, rather than discussing seriously the question of compensation to which prisoners may be entitled should the denial of their right to vote persist, debate, instead, reverted back to questions about victim compensation:

We have to make it clear that we are not prepared to allow compensation. However, if these people do manage ... to claim compensation, would it be beyond the wit of the House to help their victims and families to claim part of that new-found wealth as part of the compensation for the distress that they have suffered? (Steve McCabe, Labour: Hansard, HC Debates, vol. 523, cols 542-3, 10 February 2011)

We should take the very simple step of amending the Limitation Act 1980, so that anybody who receives damages arising from litigation on this subject can have the damages taken

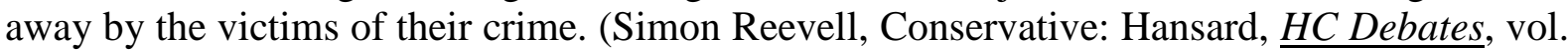
523, col. 555, 10 February 2011)

In the above debate, there is a notable absence of consideration of the ways in which the foundations of the democratic system are being undermined by denying the vote to citizens 
who have become imprisoned. 'Civil death' is not a necessary condition of the practice of imprisonment. Further, acquiescing to the demands of the majority in the interests of democratic governance has been persuasively argued against by Snacken (2010). She states: '[Populist punitiveness] is contrary to the concept of a "democratic constitutional state", which aims at the general interest and protects the fundamental rights of minorities, including unpopular minorities such as offenders or prisoners, from the "tyranny of the majority"' (de Toqueville 1835/1956, cited in Snacken 2010, p.280). Within debates on prisoners' voting and human rights it is helpful to project ourselves into the position of subject rather than aligning ourselves with the majority on these issues. As Zedner (2005) has pointed out: ‘... if rights make sense at all then the invasion of a strong right must be a very serious matter. It means treating a man as less than a man or as less worthy of concern than other men' (p.519).

Moreover, Uggen and Matza (2004) and Easton (2009) have argued that there is rehabilitative potential in the exercising of the vote in a democratic system. In empirical analyses, Uggen and Matza (2004) revealed consistent differences in subsequent arrest rates, imprisonment and self-reported criminality between voters and non-voters (p.213). It is possible, then, that the social inclusion of prisoners (and ex-prisoners) might be facilitated to some extent where their participation in democratic processes is encouraged, rather than barred. On this, Easton (2009) has argued that whilst extending the vote to prisoners would not guarantee their substantive rights, it would go some way to centralising social inclusion as an essential element of citizenship

The above arguments however, have received little serious consideration in public and political discourses. In much of the media reporting on the rights of victims and the rights of prisoners, a frequently-touted argument is encapsulated in the question: where was the respect for the victim's human rights when this crime was taking place? Such a question confuses debates on human rights and who is protected from whom through the attendant legislation. 
Becoming a victim of a violent crime at the hands of another member of society is not a human rights' violation per se. Human rights’ legislation and protections were put in place to protect us from overuses or abuses of authority by the State, not from each other. It is difficult to follow a logic that suggests that the repeal of human rights' legislation for prisoners or the disregard of their human rights' protections will somehow create a fairer criminal justice system that better protects the interests of victims. Human rights - that is protection from the State - should be extended equally to all members of society, no matter what their conduct or status. As Snacken (2010) has argued:

The protection of human rights is at the very core of the political construct of a democratic constitutional state ... [Human rights] work as a shield or a bulwark to protect individuals against excessive steering of their lives and entitle individuals to determine freely and autonomously their lives and choices and to participate in the political system. (p.281, italics in original)

\section{The Construction of a False and Fruitless Dichotomy}

Debating questions about human rights' legislation alongside questions about the rights to which victims and 'offenders' are entitled, obfuscates the problem of Britain's compliance with human rights' legislation and the treatment of both victims and perpetrators by the criminal justice system. Positioning 'victims' and 'offenders' in different citizenship categories produces an artificial delineation between citizens - all of whom are deserving of protection from abuse at the hands of the State (through human rights' legislation), protection from each other (through criminal justice processes) and fair and equitable treatment when each comes into contact with the criminal justice system.

Utilising the plight of victims within debates on human rights or on prisoners' voting and, thereby, citizenship rights, is a troubling tactic. First, such strategies indicate a tendency to stifle debate on the implications of human rights' rulings whilst evading the proper scrutiny 
of future criminal justice legislation. This was evidenced in a coda to the debate on prisoner voting which occurred six days later after the government announced that it would be introducing a mechanism for review for those subject to indefinite inclusion on the UK 'sex offenders register'. This was prompted by a UK Supreme Court judgment in the case of $\underline{R \&}$ Thompson v. Secretary of State for the Home Department ([2010] UKSC 17) ruling that lifetime inclusion on the register without the right of review was a violation of Article 8 of the Human Rights Act (the right to privacy and family life). A statement by the Home Secretary, Theresa May, and the short debate which followed was, once again, pre-empted by comments made during Prime Minister’s questions:

Philip Davies (Shipley) (Con.): After votes for prisoners, we now have the potential for human rights legislation to give sex offenders the opportunity to come off the sex offenders register. Is the Prime Minister aware that my constituents are sick to the back teeth of the human rights of criminals and prisoners being put before the rights of law-abiding citizens in this country? Is it not time that we scrapped the Human Rights Act and, if necessary, withdrew from the European convention on human rights?

The Prime Minister: My hon. Friend speaks for many people in saying how completely offensive it is, once again, to have a ruling by a court that flies in the face of common sense. Requiring serious sexual offenders to sign the register for life, as they now do, has broad support across this House and across the country. I am appalled by the Supreme Court ruling. We will take the minimum possible approach to this ruling. (Hansard, HC Debates, vol. 523, col. 955, 16 February 2011, italics added)

In his critique of popular sociology, Gramsci (1971) posits that common sense is 'the philosophy of non-philosophers', ideas which are distinguished by their 'fragmentary, incoherent and inconsequential' character (p.419). Worrall (1990, pp.18-19) describes the goal of common sense as 'the reproduction of consensus', noting that: 'It is truth which is not accessible to rational thought or argument. On the contrary, it is intuitive, instinctive, and accessible only to the senses'. In this context, Cameron's statement can be viewed as not only relying upon long-standing notions of the 'dangerous other' (see Garland 2001) but also its appeal to populist sensibilities and 'gut instinct'. ${ }^{2}$ The construction of a conflict between 
'offenders' human rights and those of crime victims was evident once again in later exchanges on the Supreme Court ruling between the Home Secretary and her Shadow:

The Secretary of State for the Home Department (Mrs Theresa May): ... Those are rights, of course, that those offenders have taken away from their victims in the cruellest and most degrading manner possible ... It is time to assert that it is Parliament that makes our laws, not the courts; that the rights of the public come before the rights of criminals ...

Yvette Cooper (Normanton, Pontefract and Castleford) (Lab.): ... the Home Secretary will know that the public would be horrified if the rights, or even the convenience, of people who have been convicted of very serious crimes were to be put above the right to safety and family

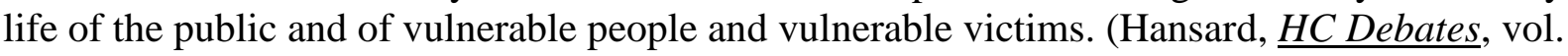
523, cols 959-61, 16 February 2011)

In both of the above exchanges, the continued confusion over the way human rights are understood and discussed in these debates is evident. As already stated, human rights' legislation is not intended to protect citizens from each other. It is intended to protect members of society from excessive State intervention. If 'constituents' are raising concerns over the extent to which State bodies, such as the police or social services, effectively carry out their work to protect social members from each other, then that is quite another matter. Crucially, however, it is not a problem with human rights' legislation.

Second, the discourses utilised in these debates reinforce the enduring stigmatising effects of imprisonment through the creation of a false 'victim or offender' dichotomy. Evidence for a false dichotomy between victims' and offenders' rights can be found in research which highlights the interchangeable nature of victimisation and offending, particularly amongst women and younger offenders. Corston (2007), in a review of vulnerable women in prison, found that over half reported having suffered domestic violence and one in three had experienced sexual abuse. Douglas, Plugge and Fitzpatrick (2009), in a study of the impact of imprisonment on women's health, found evidence suggesting that some women prisoners actually saw incarceration as an opportunity for respite from such victimisation (see also Rowe 2011). In relation to younger people, longitudinal studies have 
found evidence for causal links (in both directions) between offending and victimisation in a cohort of 4,300 young people (Smith 2004; Smith and Ecob 2007). Offending behaviour or experiences of victimisation are not fixed positions, yet current debates seem to crudely shape them as such. Whilst political discourse encourages members of the public to show compassion towards victims and to see them as a vulnerable, but deserving group, it simultaneously castigates the actions of 'offenders' whilst carelessly ignoring the fact that many individuals might fall into both categories.

Third, the rhetorical division between victims and lawbreakers may undermine opportunities for the successful reintegration of ex-prisoners back into society (see also the extensive work on the question of disenfranchisement in the US by Uggen and Manza (2002, 2004, 2005)). The recent implementation of the Prisoner's Earnings Act 1996 provides a useful example. A striking exception to calls for an end to 'compensation culture' can be found within Prison Service Instruction 48/2011 which allows for the deduction of a levy of $40 \%$ of prisoners' net earnings over $£ 20$ to be paid to the charity, Victim Support. Critics of the 'victims' levy' have claimed that it may well, in fact, be counterproductive and will hamper the resettlement of those who, in many cases, have not committed offences for many years (Harmsworth 2011). Yet, support for the creation of such a policy can be clearly linked to statements such as those outlined in parliamentary debate.

Finally, we suggest that the focus on punishing 'offenders' deflects attention from much-needed discussions of how the criminal justice system treats victims. By arguing that victims' rights can be won by removing rights from prisoners, there is little consideration given to how victims might be better supported. And, as argued earlier in this article, there is no evidence or persuasive argument to support the view that the criminal justice system is in need of rebalancing in this way (Loader 2006). Moreover, the removal of a 'right' from lawbreakers has been seen to foreshadow its removal or curtailment from all members of 
society - including victims. In 2011, the government announced its desire to ban 'convicted criminals' from 'claiming compensation for injuries sustained in attacks, in prison or after release'. This policy related to payments from the Criminal Injuries Compensation Authority - a body established by the Home Office in 1995, which pays compensation to those physically or mentally injured as the result of violent crime. Philip Davies, a back-bench Conservative MP, was unequivocal in his support for the proposal and was quoted as saying that: 'It is an outrage and a scandal that so much taxpayers' money is being wasted on compensating criminals, who most people would think lost the right to make these claims' (Independent, 27 December 2011). Similarly, a 'senior source' in the Ministry of Justice claimed that: 'It is ridiculous that we are continuing to spend so much money on the injuries sustained by convicted criminals when so many victims of crime are still waiting for funds' (Independent, 27 December 2011). Yet what was interesting about this development is that within a year, the removal of compensation for criminal injuries from prisoners was being extended to all members of the public through a drastic scaling back of compensation to all but the 'most seriously injured' victims (Independent, 27 November 2012).

\section{Conclusion}

Human rights, prisoners voting rights, the rights of persons accused and convicted of criminal conduct, and the rights of victims of crime, are all central issues in contemporary political and criminal justice debates. In much of the media coverage on prisoners' voting rights and in political debate on this issue there is an apparent assumption that granting these rights will lead to widespread hostility amongst the general public and continued opposition within parliament. Moreover, the apparent hostility within some public and political spheres toward human rights' provision for accused persons, prisoners and ex-prisoners, adds a significant and obfuscating barrier when attempting to debate the questions about current approaches to crime control, criminal justice, and victim support. Rational debate seems beyond the grasp 
of political actors when the rights of victims and offenders are viewed in opposing categories. In this context, victims are not understood as a deserving group in their own right or in need of meaningful State-sponsored support. The potential for improvements to victims' services becomes lost in the battle of offenders' versus victims' rights with neither group benefiting substantially, and indeed, in the wake of the conflict, the social status of prisoners becomes even more marginal. In Britain, prisoners and ex-prisoners become 'others', in not just rhetorical, but material, terms. Their criminal records that follow them out into society after release contribute significantly to their continued social exclusion and feelings of stigmatisation (Social Exclusion Unit 2002; Unlock 2009; Working Links 2010; Aresti, Eatough and Brooks-Gordon 2010; Nacro 2010; see also Pager (2007) in the US). Yet the denial of their voting rights in custody makes their continued exclusion even more likely and serves only to exacerbate their sense of detachment from active citizenship. Their construction as 'expelled citizens' (or rather reconstruction as 'denizens' or even 'social outcasts') are likely to retain much more salience than any sense of ‘social belonging' or inclusiveness.

One means by which those who have contravened the law might become more committed to democratic values and social responsibility is through exercising their political rights through voting. By the State not recognising these rights, successful reintegration back into society after imprisonment is further hindered. As van Zyl Smit and Snacken (2009) have argued: ' ... to strip prisoners of their most basic rights of citizenship, such as the right to vote, will isolate them from their communities and threaten their capacity to establish or maintain successful adult roles, which are important in the process of desisting from crime' (p.254). Desistance research has considered the potential of civil reintegration ceremonies and processes of ‘judicial rehabilitation’ where courts can 'wipe the record clean' for individuals as a means of destigmatisation (Maruna 2011; Padfield 2011; see also Earle and Wakefield (2012) on the need to 'deinstitutionalise' the stigma of criminal records). However, given the 
prevalence of the 'anti-offender' political rhetoric outlined in this article (which seems to be continuing unabated), it is unlikely that such progressive ideas will achieve recognition any time soon. That is, perhaps, until they are more effectively constructed in a way that demonstrates their benefit to the potential future victims of recidivist crime, thus making them a more palatable option for politicians and the public alike. ${ }^{3}$

\section{Notes}

${ }^{1}$ The continued disregard of its commitment to the ECHR by the UK government is a theme which re-emerged in a more recent debate on the issue of Abu Qatada's (non-)deportation (see Hansard, HC Debates, vol. 561, cols 887-900, 24 April 2013).

${ }^{2}$ Professor Vernon Bogdanor, who was David Cameron’s politics tutor at Oxford University once made the following comments in response to his former students' claim that a 'British Bill of Rights' was required to replace the Human Rights Act: 'I think he is very confused. I've read his speech and it's filled with contradictions. There are one or two good things in it but one glimpses them, as it were, through a mist of misunderstanding' (Guardian, 1 July 2006).

${ }^{3}$ Acknowledgements: We are grateful to the anonymous reviewers for their helpful comments and suggestions of additions to this article.

\section{References}

Aresti, A., Eatough, V. and Brooks-Gordon, B. (2010) 'Doing time after time: an interpretative phenomenological analysis of reformed ex-prisoners' experiences of selfchange, identity and career opportunities', Psychology, Crime \& Law, 16(3), 169-90.

Bednarova, J. (2011) 'The heart of the criminal justice system: a critical analysis of the position of the victim', International Journal of Criminology (online). Available at: http://www.internetjournalofcriminology.com/Bednarova_The_Heart of the_Criminal _Justice_System.pdf (accessed 21 June 2013).

Bottoms, A.E. (1983) 'Neglected features of the contemporary penal system', in: D. Garland and P. Young (Eds.), The Power to Punish, London: Heinemann. 
Bottoms, A.E. (1995) 'The philosophy and politics of punishment and sentencing', in: C. Clarkson and R. Morgan (Eds.), The Politics of Sentencing Reform, Oxford: Clarendon Press.

Chaplin, R., Flatley, J. and Smith, K. (2011) Crime in England and Wales 2010/11, London: Home Office.

Cheliotis, L. (2010) 'The ambivalent consequences of visibility: crime and prisons in the mass media', Crime, Media, Culture, $\underline{6}$ (2), 169-84.

Cohen, S. (2002) Folk Devils and Moral Panics, 3rd edn, London: Routledge.

Coleman, C. and Moynihan, J. (1996) Understanding Crime Data: Haunted by the Dark Figure, Maidenhead: Open University Press.

Corston, J. (2007) The Corston Report, London: Home Office.

de Toqueville, A. (1835/1956) Democracy in America, New York: Mentor Books.

Dignan, J. (2005) Understanding Victims and Restorative Justice, Maidenhead: Open University Press.

Douglas, N., Plugge, E. and Fitzpatrick, R. (2009) 'The impact of imprisonment on health: what do women prisoners say?', Journal of Epidemiology and Community Health, 63(9), 749-54.

Downes, D. (1998) 'Toughing it out: from Labour opposition to Labour government', Policy Studies, $\underline{19}(3), 191-8$.

Downes, D. and Morgan, R. (2002) 'The British General Election 2001', $\underline{\text { Punishment and }}$ Society, $4(1), 81-96$.

Drake, D. (2011) 'The “dangerous other” in maximum-security prisons’, Criminology and Criminal Justice, 11(4), 367-82.

Drake, D. (2012) Prisons, Punishment and the Pursuit of Security, Basingstoke: Palgrave.

Earle, R. and Wakefield, A. (2012) 'Restorative justice and the right to move on: deinstitutionalising the stigma of a criminal conviction in England and Wales', in: T. Gavrielides (Ed.), Rights and Restoration within Youth Justice, Whitby, ON.: de Sitter Publications.

Easton, S. (2009) 'The prisoner's right to vote and civic responsibility: reaffirming the social

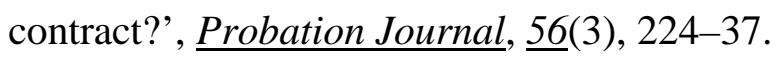

Easton, S. (2011) Prisoner's Rights: Principles and Practice, Abingdon: Routledge.

Garland, D. (2001) The Culture of Control: Crime and Social Order in Contemporary Society, Oxford: Oxford University Press.

Gramsci, A. (1971) Selections from the Prison Notebooks, London: Lawrence and Wishart. 
Green, D.A. (2008) When Children Kill Children: Penal Populism and Political Culture, Oxford: Clarendon.

Hall, M. (2009) Victims of Crime: Policy and Practice in Criminal Justice, Cullompton: Willan.

Harmsworth, J. (2011) The Victims Levy: Undermining Rehabilitation, Snodland, Kent: Unlock, the National Association of Reformed Offenders.

Haydon, D. and Scraton, P. (2000) ““Condemn a little more, understand a little less”: the political context and rights' implications of the domestic and European rulings in the Venables-Thompson case', Journal of Law and Society, 27(3), 416-48.

Home Office (2006) Rebalancing the Criminal Justice System in Favour of the Law-Abiding Majority, London: Home Office.

Karmen, A.J. (1992) 'Who's against victims' rights? The nature of the opposition to provictim initiatives in criminal justice', Saint John's Journal of Legal Commentary, $\underline{8}$, $157-75$.

Karstedt, S. and Farrall, S. (2006) 'The moral economy of everyday crime: markets, consumers and citizens', British Journal of Criminology, 46(6), 1011-36.

Loader, I. (2006) 'Re-balancing the criminal justice system?: A response to Tony Blair', $\underline{B B C}$ News Online, 23 June. Available at: http://news.bbc.co.uk/1/hi/uk_politics/5108972.stm (accessed 30 September 2013).

Maruna, S. (2011) 'Judicial rehabilitation and the "clean bill of health” in criminal justice', European Journal of Probation, 3 (1), 97-117.

Mason, P. (2007) 'Misinformation, myth and distortion: how the press construct imprisonment in Britain', Journalism Studies, $\underline{8}(3), 481-96$.

Ministry of Justice (2010) Breaking the Cycle: Effective Punishment, Rehabilitation, and Sentencing of Offenders, London: HMSO.

Ministry of Justice (2011) Breaking the Cycle: Government Response, London: HMSO.

Ministry of Justice (2012) About the Victims' Commissioner (online). Available at: http://www.justice.gov.uk/about/vc/ (accessed 3 May 2013).

Nacro (2010) Change the Record: Nacro's Campaign Report, London: Nacro.

Padfield, N. (2011) 'Judicial rehabilitation? A view from England', European Journal of Probation, $\underline{3}(1), 36-49$.

Pager, D. (2007) Marked: Race, Crime, and Finding Work in an Era of Mass Incarceration, Chicago, IL.: University of Chicago Press. 
Pratt, J., Brown, D., Brown, M., Hallsworth, S. and Morrison, W. (Eds.) (2005) The New Punitiveness: Trends, Theories, Perspectives, Cullompton: Willan.

Rowe, A. (2011) 'Narratives of self and identity in women's prisons: stigma and the struggle

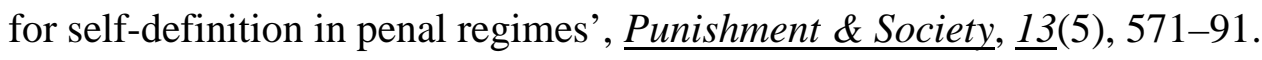

Sanders, A. (2002) 'Victim participation in an exclusionary criminal justice system', in: C. Hoyle and R. Young (Eds.), New Visions of Crime Victims, Portland, OR.: Hart.

Sim, J. (2009) Punishment and Prisons: Power and the Carceral State, London: Sage.

Smith, D. (2004) The Edinburgh Study of Youth Transitions and Crime: The Links Between Victimization and Offending, Edinburgh: Centre for Law and Society, University of Edinburgh.

Smith, D. and Ecob, R. (2007) 'An investigation of causal links between victimization and offending in adolescents’, British Journal of Sociology, 58(4), 633-59.

Snacken, S. (2010) 'Resisting punitiveness in Europe?', Theoretical Criminology, 14(3), 27392.

Social Exclusion Unit (2002) Reducing Re-offending by Ex-prisoners, London: Office of the Deputy Prime Minister.

Standing, G. (2011) The Precariat: The New Dangerous Class, London: Bloomsbury.

Uggen, C. and Manza, J. (2002) 'Democratic contraction? The political consequences of felon disenfranchisement', American Sociological Review, 67, 777-803.

Uggen, C. and Manza, J. (2004) 'Voting and subsequent crime and arrest: evidence from a community sample’, Columbia Human Rights Law Review, 36, 193-215.

Uggen, C. and Manza, J. (2005) 'Disenfranchisement and the civic reintegration of convicted felons', in: C. Mele and T. Miller (Eds.), Civil Penalties, Social Consequences, New York: Routledge.

UK Government (2010) Government Approach to Prisoner Voting Rights (online). Available at: https://www.gov.uk/government/news/government-approach-to-prisoner-votingrights (accessed 7 May 2013).

UK Government (2012) Crime and Justice Speech (online). Available at: https://www.gov.uk/government/speeches/crime-and-justice-speech (accessed 7 May 2013).

Unlock (2009) Unlocking Employment: Briefing Paper on the Second Reading of the Rehabilitation of Offenders Act (Amendment) Bill, Snodland, Kent: Unlock. van Zyl Smit, D. and Snacken, S. (2009) Principles of European Prison Law and Policy: Penology and Human Rights, Oxford: Oxford University Press. 
Walker, J.T. and Boyeskie, J.A. (2001) 'The discourse of criminality: from Beccaria to postmodernism', Critical Criminology, 10,107-22.

Walklate, S. (2007) Imagining the Victim of Crime, Maidenhead: Open University Press.

Webster, C., MacDonald, R. and Simpson, M. (2006) 'Predicting criminality? Risk factors, neighbourhood influence and desistance', Youth Justice, $\underline{6}$ (1), 7-22.

Williams, B. (2005) Victims of Crime and Community Justice, London: Jessica Kingsley.

Working Links (2010) Prejudiced: Tagged for Life, London: Working Links.

Worrall, A. (1990) Offending Women, London: Routledge.

Zedner, L. (2004) Criminal Justice, Oxford: Oxford University Press.

Zedner, L. (2005) 'Security liberty in the face of terror: reflections from criminal justice', Journal of Law and Society, 32(4), 507-33.

Zimring, F.E. and Johnson, D.T. (2006) 'Public opinion and the governance of punishment in democratic political systems’, in: S. Karstedt and G. LaFree (Eds.), Democracy, Crime and Justice: The Annals of the American Academy of Political and Social Sciences, London: Sage.

Date submitted: May 2013

Date accepted: July 2013 